DOI: $10.1515 / \mathrm{rpp}-2017-0002$

Doctor of Pedagogical Sciences, Senior Research Fellow, MYROSLAVA VOVK Institute of Pedagogical Education and Adult Education of NAPS of Ukraine Address: 9 M. Berlynskoho St., Kyiv, 04060, Ukraine

E-mail: miravovk@mail.ru

\title{
TRENDS IN FOLKLORE STUDIES DEVELOPMENT IN THE RESEARCH AND EDUCATION SPACE AT UKRAINIAN AND FOREIGN UNIVERSITIES
}

\section{ABSTRACT}

Trends in development of folklore studies in the research and education space at Ukrainian and foreign universities have been analyzed. They are fundamentalization, synthesis of academic science and educational practice, professionalization, institutionalization, humanitarization, anthropoligization, interdisciplinarity. It has been defined that in Ukrainian and foreign folkloristic discourse of the $20^{\text {th }}$ - the beginning of the $21^{\text {th }}$ centuries, folklore is studied through the prism of functional, communicative, anthropological, context-based approaches that is partially realized in the official definition of folklore according to the 1989 UNESCO Recommendation on the Safeguarding of Traditional Culture and Folklore. It has been found out that while structuring the content of folkloristic disciplines as well as directing future specialists' researches the multivectoring of folklore studies allows instructors to use the achievements of folkloristic directions that were formed in historical retrospective and actively developed at the modern stage: linguofolkloristics, ethnomusicology, folk therapy (folk music therapy, fairytale therapy, folk dance therapy), etc. It has been justified that folklore studies in Ukrainian and foreign research and education space is being developed as an interdisciplinary science based on the historical and pedagogical experience and taking into account modern integration processes that define the problematics of the content of folkloristic, culturological training of future pedagogueresearcher who is to be educated as a man of culture, nationally aware and, at the same time, multicultural personality.

Key words: folklore, folklore studies, university, trends, historical and pedagogical experience, interdisciplinarity, fundamentalization.

\section{INTRODUCTION}

Transformational changes in modern educational space are connected with the need for forming a new type of future pedagogue-researcher - a man of culture, nationally aware and, at the same time, multicultural personality, a multiculturally sensible man. Consequently, education should adapt to modern sociocultural conditions based on the historically formed scientific experience and traditions of educational practice as well as take into account modern trends in development of certain scientific and educational fields in the international context. This problem is rather topical for folklore studies - the philological, culturological, humanitarian, anthropological science that studies folklore as a syncretic phenomenon of culture in its genre and specific variety, regional and international dimensions, defines methodological tools for analysis of folklore texts, explores the activity of well-known and unknown folklorists. In terms of university education, folklore studies as a science developed during $19^{\text {th }}-20^{\text {th }}$ centuries in Ukraine and abroad. Within universities scientific folklore schools appeared, traditions of interdisciplinary researches 
on folklore developed as well as professional folklore foundations for training of future philologists, folklorists, culture experts, ethnographers were formed.

THE AIM OF THE STUDY

The aim of the study is to analyze trends in development of folklore studies in the research and education space at Ukrainian and foreign universities based on taking into account theoretical and practical experience in the study of folklore traditions in terms of university education formed in historical retrospective and modern vectors in development of humanitarian, philological and anthropological scientific and educational fields.

THEORETICAL FRAMEWORK AND RESEARCH METHODS

In Ukrainian and foreign folkloristic discourse of the $20^{\text {th }}-$ early $21^{\text {th }}$ centuries, folklore is studied through the prism of functional, communicative, anthropological, context-based approaches that is partially realized in the official definition of folklore according to the 1989 UNESCO Recommendation on the Safeguarding of Traditional Culture and Folklore (UNESCO, 1989). Polish (J. Bartmiński, V. Krawczyk-Wasilewska), Ukrainian (V. Davydiuk, S. Hrytsa, O. Kychenko) and Russian (K. Chystov, B. Putilov,) scholars-folklorists and pedagogues scientifically justified these approaches. At the same time, the historical-pedagogical analysis of theory and practice of folklore studies at Ukrainian and foreign universities proves that in terms of interdisciplinarity and integration of sciences one can define leading trends in development of folklore studies in Ukrainian and foreign research and education space.

Based on the comparative analysis of main principles of culturological, axiological, systemic and multicultural approaches we can define leading trends in development of folklore studies in the research and education space at Ukrainian and foreign universities taking into account national and foreign achievements of humanitarian, philological, anthropological sciences and educational traditions.

\section{RESULTS}

The leading trend in development of modern higher education and, in particular, the folkloristic environment, is fundamentalization that, according to O. Meshchaninov, is regarded as an element of "proactive learning, i.e. the fundamental foundation for transition towards sustainable development" (Мещанінов, 2005). In the context of forming theory and practice of folkloristic studies, fundamentalization is a defining trend in the activity of Ukrainian and foreign universities. This is best illustrated by the development of folkloristic centers in Lviv and Kyiv as well as the forming of one in Cherkasy. The folkloristic center in Lviv is developed on the basis of ideas, theoretical and methodological approaches to the study of regional folklore, ethnomusicological problematics justified in works of scholarspedagogues from Lviv University, namely, I. Denysiuk, A. Fisher, Ya. Holovatskyi, F. Kolessa, T. Komarynets, O. Ohonovskyi and others. Theories, conceptions, practical experience in exploring the folklore tradition by instructors from Kyiv University (V. Boiko, M. Dashkevych, L. Dunaievskyi, M. Hrytsai, O. Kotliareskyi, A. Loboda, M. Kostomarov, V. Peretts) is based on functional, context-based, anthropological approaches to the study of folklore.

In Poland there are certain scientific schools based on universties: Warsaw (the main directions of activity are based on the systematization folklore phenomena, study of the relations between folklore and literature as well as the history of folklore studies (the students of prof. Yu. Krźyźanowski)); Opole, headed by D. Simonides (its scientific interests consist in field-based collecting materials, publishing texts and studying folklore studies as an environement of social diagnostics); Wroclaw (it studies the problems of historical semantics of culture, admits the complexness of methods and sources of 
historical, sociological, philological type (the students of prof. C. Hernas); Lublin (it is engaged in analyzing the problems of linguistic stereotype, a cultural symbol, poetics of an oral text, narratology, a linguistic image of the world (the followers of prof. J. Bartmiński's ideas) (Бартминьский, 2004).

The fundametality of scientific and educational traditions in the study of folkloristics is revealed in the context of synthesis of university education and academic science. In Ukraine the activity of academic folkloristic centers (the department of foreign and Ukrainian folkloristics at the Rylskyi Institute of Art Studies, Folkloristics and Ethnology of the National Academy of Sciences of Ukraine, the department of folkloristics at the Ethnology Institute of the National Academy of Sciences of Ukraine, etc.) is directed at improving the system of future philologists and folklorists' folkloristic training; composing reference guides, monographs, recommendations on the activization of research activities, publishing periodicals in folklore and ethnography (such as "Narodna tvorchist ta etnologia" (Folk Art and Ethnology), "Folklorystychni zoshyty" (Folkloristic Notes), "Narodoznavchi zoshyty" (Ethnological Notes), "Mifologia i folklor" (Mythology and Folklore), etc.). In the Center of Folklore Typology and Semiotics at the Russian State University for Humanities, the training of future specialists is connected with research activities within a "live" folklore or academicfolkloristic environment (Российский государственный гуманитарный университет, 2017).

The trend of institutionalization is observed in functioning of folkloristic centers, namely, those establishments, institutions where folklore is studied in the context of different subfields (source criticism, textology, linguofolkloristics, ethnomusicology, etc.) in association with allied sciences, different types of art. As a result, they publish various periodicals, series of folkloristic works, collections of articles as well as organize international, all-Ukrainian, regional conferences on the problems of folklore studies, etc.

Ukrainian folkloristic centers include specialized departments at universities (the Filaret Kolessa Ukrainian folklore studies department at Ivan Franko National University of Lviv, the department of folklore studies at Petro Tchaikovskyi National Music Academy of Ukraine, the department of folklore music at Rivne State University of Humanities, etc.); academic centers; centers of folklore, laboratories at universities (the Center of Studies on Bukovyna at Yuriy Fedkovych Chernivtsi National University, the laboratory of Ukrainian folklore studies at Ivan Franko National University of Lviv, the Center of Ethnology in Cherkasy Region at Pavlo Tychyna Uman State Pedagogical University, etc.). In addition, there is the Ukrainian Society of Folklore and Mythology Researchers (Lviv) and they publish the periodical "Mifologia i folklor" (Mythology and Folklore).

In foreign scientific and educational space there is a range of societies, organization engaged in folklore studies, whose activity caused traditional and innovative foundations in the study of folklore. Particular attention deserves the experince in studying the folklore tradition in the USA, that is connected with the activity of the American Folklore Society founded in 1888 in Massachusetts with the participation of Mark Twain and R. B. Hayes, the President of the USA at that time. Nowadays, this is a professional society that unites famous young scholars-pedagogues of anthropology, folklore studies, ethnology and culturology (The American Folklore Society, 2017). At Memorial University, Canada, there is the MUN Folklore Society that contributes to involving students in discussions around academic problems while studying folklore (Memorial University, 2017). In Great Britain there is the Folklore Society founded in 1878 in London that is aimed at studying folklore around the world (The Folklore Society, 2017). 
One of the forms of institutionalization in the field of folklore studies is a cultural museum. The historical and pedagogical analysis of folklore studies development at Ukrainian universities proves that functioning of ethnographic museums and museums of antiquity at universities is connected with forming of professional foundations in the organization of folkloristic (folklore) practice as well as the activization of students' research activities (Kharkiv University, Lviv University). Currently, within universities and academic centers there are the museums that have their own historical tradition (the Museum of Archeology and Ethnography of Slobidska Ukraine at V. N. Karazin Kharkiv National University, the Museum of Ethnography and Arts and Crafts at the Ethnology Institute of the National Academy of Sciences of Ukraine, etc.).

Foreign experience in organizing the museums aimed at preserving popular traditions, material culture proves the context-based study of folklore. In particular, at the University of Cambridge there is the Museum of Archeology and Anthropology engaged in the study of culture, legends, music and choreographic art in the UK (The University of Cambridge, 2017). Since 1948 the Folklore Society has been functioning at the University of Oxford. Its main aim consists in collecting, recording and studying regional folklore as well as folklore around the world (Oxford Reference, 2017).

Professionalization is associated with the trend of systematization, i.e. classification of folklore material, presentation of results of folkloristic activity with the use of modern information technologies and techniques. Systematization in folklore studies is revealed through creation of e-databases, e-archives and e-labs. The first e-lab of folklore studies, where the most significant works on the history of forming scientific and folkloristic schools, traditions of collecting folklore texts are presented, was established by instructors from the Filaret Kolessa Ukrainian folklore studies department at Ivan Franko National University of Lviv (Львівський національний університет імені Івана Франка, 2017). With the participation of Polish folkloristic and culturological centers various periodicals are published systematically presented in electronic libraries ("Etnolinhvistyka" (Ethnolinguistics), "Pamiatnyky literaturni" (Literary Monuments), "Literaturoznavstvo. Kulturologia. Folklorystyka" (Literary Studies. Culturology. Folklore Studies), "Literatura narodna" (Folk Literature), etc.) and being a unique resource of modern theories, conceptions and traditions of Polish folkloristic thought.

One of the most important trend in folklore studies development in foreign and Ukrainian educational and scientific practice is humanitarization that presupposes taking into account such theoretical and content aspects of education as the need for understanding the world's cultural and historical heritage, comprehending the national cultural experience of previous epochs and modernity, personality self-development and self-actualization by enhancing their professional, spiritual and creative levels, etc. The trend of humanitarization within the folkloristic research and education space is manifested in the differentiation of folkloristic disciplines at Ukrainian and foreign universities. In the context of these disciplines folklore is studied through the prism of functional, communicative, anthropological, context-based approaches that is proved by the official definition of folklore according to the 1989 UNESCO Recommendation on the Safeguarding of Traditional Culture and Folklore (UNESCO, 1989).

At this period, one can observe "anthropologization" of folklore studies, which is why methods and techniques of allied fields (the theory of communications, cognitology, psychology, sociology, etc.) are used as an analytical toolset. Thus, in Polish research space understanding of folklore varies between two definitions, namely, philological or linguistic 
one, that, first of all, reveals the verbal aspect of analysis of folklore texts and its interpretation according to the culturological and semiotic conceptions that encompass both the verbal layer of culture and beliefs, rituals, elements of visual arts, clothing, dwelling, that, in other words, is folk culture in general. Scholars justify the theories of identification of folklore studies with culturology (Бартминьский, 2005).

At Harvard University folkloristic and ethnological disciplines are basic in the historical and philological training of future specialists. The problematics of these disciplines lays the basis for problem-based courses and special courses that involve the study of main forms of folklore (myths, legends, epic works, beliefs, rituals, celebrations), justification of theoretical foundations of their analysis, investigation of the problems of transferring national, ethnical and cultural identity through the prism of folklore, analysis of its impact on everyday life, determination of specifics in functioning of folkloristic traditions within social, ethnical groups (The Harvard University, 2017).

Such an approach can be traced in the context of future philologists and folklorists' folkloristic training at classical universities in Ukraine. Since the beginning of 1990s at Taras Shevchenko Kyiv National University, Ivan Franko National University of Lviv the content of courses and special courses is structured based on the study of folklore in the context of anthropology as well as conducting a comparative analysis with other cultural phenomena, art works, psychology, modern philosophy and functional figurativeness.

The differentiation of folkloristic disciplines in training of future pedagoguesresearchers is connected with the trend of integration. Analysis of modern state of foreign and native theory and practice of folklore studies proves that integration processes have defined the problematics of culturological, anthropological, ethnological disciplines and topicality of scientific studies. In particular, over the last decades folklore studies in Poland have been directed at the study of folklore in the context of allied disciplines (literary studies, linguistics, religious studies, musicology, theatre studies, ethnography, sociology, culturology). The leading direction of Polish folklorists is Ethnolinguistics founded on the traditions of W. von Humboldt, E. Sapir, developed by Moscow researches such as V. Ivanov, V. Toporov, M. Tolstoi and others. In Poland this direction is based on cognitivism and cultural anthropology (Бартминьский, 2005).

Professional training of philologists, historians, ethnologists at at the University of Oxford pressuposes free choice courses and special courses in philology, folkloristics, ethnology based on the integration relations with other cultural fields and scientific directions. The content of the courses is based on the analysis of cultural and artistic factors of folklore studies in historical retrospective (Oxford Reference, 2017).

The specifics of future philologists and folklorists' folkloristic training at Ukrainian universities is the study of folklore from the angle of different sciences based on interdisciplinarity that creates opportunities for a multiaspectual analysis of Ukrainin and foregn folkloristic experience. While structuring the content of folkloristic disciplines multivectoring of folklore studies allows instructors to use the achievements of folkloristic directions that were formed in historical retrospective and are actively developed at the modern stage: linguofolkloristics, ethnomusicology, folk therapy (folk music therapy, fairytale therapy, folk dance therapy), etc.

\section{CONCLUSIONS}

The determination of trends in folklore studies at Ukrainian and foreign universities has allowed to define the following: folklore is studied through the prism of functional, communicative, anthropological, context-based approaches that defines its integrative 


\section{DE GRUYTER}

essence as a reviving source of cultural, art, scientific and educational development of society. The trends of fundamentalization, professionalization, synthesis of academic science and educational practice, institutionalization, humanitarization, anthropoligization, interdisciplinarity being defined by the experience in studying folklore studies at Ukrainian and foreign universities determine the conditions for training of a future competitive pedagogue-researcher as a man of culture who has a formed nationally conscious and multiculturally vulnerable position, is axiologically aimed at professional folkloristic (scientific or pedagogical) activity during their lifetime.

\section{REFERENCES}

1. UNESCO. (1989). The 1989 UNESCO Recommendation on the Safeguarding of Traditional Culture and Folklore. Retrieved 15.12.2016 from : http://portal.unesco.org/en/ ev.php URL_ID=13141\&URL_DO=DO_TOPIC\&URL_SECTION=201.html.

2. Memorial University. (2017). Department of Folklore. Retrieved 16.12.2016 from : http://www.mun.ca/folklore/about/.

3. Oxford Reference. (2017). Folklore Society. Retrieved 16.12.2016 from: http://www.oxfordreference.com/view/10.1093/oi/authority.20110803095826506.

4. The American Folklore Society. (2017). About the American Folklore Society. Retrieved 18.12.2016 from : http://www.afsnet.org/?page=AboutAFS.

5. The University of Cambridge. (2017). Museum of Archeology and Anthropology. Retrieved 16.12.2016 from : http://maa.cam.ac.uk.

6. The Folklore Society (FLS). (2017). About the Folklore Society. Retrieved 16.12.2016 from : http://www.folklore-society.com/aboutus/index.asp.

7. The Harvard University. (2017). The Committe on Degrees in Folklore and Mythology. Retrieved 16.12.2016 from : http://web.me.com/folkmyth/Folk_\%26_Myth/Co urses.html.

8. Бартминьский, Є. (2004). Фольклористика, этнонаука, этнолингвистика ситуация в Польше [Folklore Stufies, Ethnoscience, Ethnolinguistics - the Situation in Poland]. Славяноведение [Slavonic Studies], No 6, pp. 89-98 (in Ukrainian).

9. Львівський національний університет імені Івана Франка [Ivan Franko National University of Lviv]. (2017). Електронна навчальна бібліотека української фольклористики при кафедрі украӥнської фольклористики імені Філарета Колесси [Electronic Scientific Library of Ukrainian Folkloristics named after Filaret Kolessa]. Retrieved 12.12.2016 from : http://www.lnu.edu.ua/faculty/Philol/www/laboratory_folk_st udies/lab_folk_el_library.php.

10. Мещанінов, О. П. (2005). Сучасні моделі розвитку університетської освіти в Украӥні [Modern Models of University Education Development in Ukraine]. Миколаїв : МДГУ ім. Петра Могили, 460 р. (in Ukrainian).

11. Российский государственный гуманитарный университет [Russian State University for Humanities]. (2017). Концепция учебно-научного Центра типологии и семиотики фольклора Российского государственного гуманитарного университета [The Conception of Training Research Center of Typology and Semiotics at Russian State University for Humanities]. Retrieved 14.12.2016 from : http://www.rsuh.ru/article.html?id=393. 